\title{
Education as a spectral technology: Corporate culture at work in Ontario's schools
}

\section{Susan M. Martin}

Abstract: This paper addresses the sweeping neoliberal reforms implemented in Ontario's schools in 2000, and conceptualises them within the terms of 'millennial capitalism' (Comaroff \& Comaroff, 2000). A close reading of secondary school curriculum documents and the umbrella policies that shape education from ages 5 to 18 years reveals how students are groomed to identify themselves as workers under construction. This is accomplished by mandating career education that defines lived experience as a 'career', articulates an identity for students as workers/producers, and dictates a direct relationship between education and the health of the economy. For students the professed advantages of millennial capitalism come from freedom and choice to navigate a post-secondary future in an abstract market that rewards those who respond to its highs and lows. Despite the drop-out 'crisis' that followed the initial reforms, and the next government's efforts to remediate the damage done, ultimately corporatist/careerist mantras continue to haunt classrooms, shape education, and its aims and goals in Ontario. The analysis offered in this paper aims to help us better understand the resilience of the neoliberal agenda in the current global economic 'crisis', in light of ongoing calls for 'value-for-money' in delivering public services and overall competitiveness. Ontario's education system has a reputation internationally as a high-level performer; this positioning in light of the anomalies presented by its policy and curriculum serves as a cautionary tale to countries that connect growth in GDP with the results of its children and youth on standardised tests. Further, it reveals the disparity between statistics at the macro level and life at the level of the classroom.

Key words: educational policy, millennial capitalism, secondary school curriculum, neoliberalism, career education

\section{Introduction}

In the early 1990s Ontario, Canada, entered a deep structural recession. In 1995 the provincial election swept into power a majority Progressive Con- 
servative government on a platform promising comprehensive reforms to the delivery of public services to create a 'business-friendly' political and economic climate in Ontario that would, in turn, create jobs. Of that era Stephens (1995) observed that, globally, Third World conditions had come to First World children: pervasive economic instability and unemployment, among other indicators, meant that all children would come to know the changes in global capitalism in most areas of life. Children and youth in Ontario were no exception: the ethos of primary, middle, and secondary education soon absorbed the mantras of global capitalism through comprehensive reforms to the curriculum and its delivery. The first Minister of Education in this new government, John Snobelen, said publicly that he would "invent a crisis" so that the new government could transform education; out of necessity, he offered, the government would "have to first make sure we've communicated brilliantly the breakdown in the process we currently experience" (as cited in Sears, 2003, p. 4). News of graduates being ill-equipped for the workforce and a critical skills shortage had been part of the prevailing political narrative in the early 1990s to justify including workplace skills and drills in schooling, and a mandate for standardized testing.

Within five years of the "crisis" announced by Snobelen a neoliberal agenda, distinctly corporatist and careerist in its shaping of compulsory content, was articulating students' school lives. A palpable shift in authority had occurred in the curricula and umbrella policies: the language governing the curriculum demonstrated a privatisation 'creep' in a core public domain. Clearly global capitalism had become what Giroux (2000; 2004; 2006) would later designate as a site of public pedagogy - a site of teaching and learning inside and outside the classroom that allows capitalism to articulate social relations and civic engagement. This mandate is firmly established in the policy documents that shape the goals of education in Ontario: economic activity and workplace preparation became central to the lives of children and youth as they, in turn, became responsible for the health of the economy via their performance in school.

The larger context and shifts in the global economy during this era does, in retrospect, provide insight into the rhetorical and ideological shaping of education policy, curriculum, and classroom life in Ontario. A theoretical backdrop to the era and, vicariously, these reforms, is provided by Comaroff and Comaroff (2000). Writing of "millenial capitalism" and its positioning as a global saviour for regions, nations, and individuals, capitalism's "second coming" transformed it into emancipatory force for individuals in an unfettered marketplace (Comaroff \& Comaroff, 2000). Prior to summarising and analysing the specifics of Ontario's education reforms, a consideration of the benchmarks of "millennial capitalism" that are shared with the ethos of 
those reforms provides an understanding of how, exactly, schools came to serve as handmaidens to private interests in the macroeconomy. This theory also assists in conceptualising the resilience of this neoliberal turn despite the failings of both these reforms and the economy at large.

\section{Capitalism as Saviour, Education as a Spectral Technology}

The strength of neoliberal capitalism in light of market failures across the last decade of the twentieth century and the opening decade of the twenty-first century is found, according to the authors, in the seduction of a dual-narrative of promise and peril that combines the lure of "vast, almost instantaneous riches to those who master its spectral technologies" and the simultaneous threat to "the very existence of those who do not" (Comaroff \& Comaroff, 2000, p. 298). Distant rewards and prizes that turn fleeting allow millennial capitalism to seduce continuously and continually via promises to be inclusive "in unanticipated ways" producing, in turn, "desire and expectation" on a global scale. Simultaneously it demonstrates that it can also "marginalize in unanticipated ways" and "decrease the certainty of work or the security of persons" (p. 298). Solemn promise and ominous caution operate in concert in an ever-shifting balance, emanating from the metropolitan centres of commercial power to the margins internationally among nation-states, and nationally within populations. Each combines, in turn, with the observed or reported workings and outcomes of market activity to signal that thriving or failing to thrive in 'the market' is within the provenance of those who choose to follow its dictates and adopt its ways and means; or, in the words of Comaroff and Comaroff (2000), master its 'spectral technologies'.

Ultimately, this commercial saviour, its spectral qualities and technologies, has lent both global capitalism and neoliberal constructions of civil society a distinct position and resilience in education policy and curricula in spite of fluctuations and the recent downturn in the global economy. According to Comaroff and Comaroff (2000) critical factors such as a tighter distribution of wealth have meant that capitalism, as an ideology and a force, had to take this precise transformational turn across the 1990s: becoming 'millennial' signalled moving beyond merely global and 'free-market' into an actively evolving phenomenon that reshapes capitalism as a persistently positive force in response to both economic highs and lows. They argue that the correlation of three core elements - neoliberal discourses of what constitutes 'civil society', the "shifting provenance of the nation-state", and the "rise of new forms of enchantment" (p. 293) work separately and in concert to cement the narrative that emanates from supra-national centres 
of power that capitalism is the saviour. Nations serving as intermediaries for a de-politicised market, one that will sort social inequalities, have positioned global, neoliberal capitalism as enigmatic and salvific in the lives of their citizens. In these new positions both citizens and the nation-state serve capitalism's core authorities in a quest for common wealth promised via gains 'the market', when unregulated, may grant individuals and, ultimately, societies. For individuals the professed advantages of millennial capitalism come from freedom and choice: access to the abstract market for everything from self-directed pensions and private health care to flexible employment options, all in low-tax utopias.

In the curriculum and its delivery the approach to dealing with threats of economic insecurity remains, ironically, to threaten more insecurity not unlike the dual-narrative of promise and peril (Commaroff \& Comaroff, 2000). As such, education is offered as a do-it-yourself means to combat personal financial and macroeconomic instability rather than encouraging government-sponsored efforts to eliminate or buffer it via economic, labour, and social policies. The construction of a person's life as the sum of an 'enterprising' worker in the labour market and a consumer in the marketplace - a free agent at all sites - became the comprehensive strategy to construct a 'good life' for individuals globally under millennial capitalism (Comaroff \& Comaroff, 2000) and for students in Ontario's schools. The 'good life' provided by academic and commercial successes were scripted onto the classroom according to commercial and careerist conventions just as ubiquitous narratives about 'the market' came to signify its multiple sites of activity, and operations that are not readily identifiable or observable in motion.

According to Comaroff \& Comaroff (2000), one of the new forms of enchantment in millennial capitalism is a survivalist acumen that includes life-long learning'. Dominating schools and classrooms under the reforms is the mercurial and ubiquitous message that education is primarily about individuals seeking employment and the security that comes from earning in the future through their actions and choices now in childhood and adolescence. The shift in the centrality of the state to the individual in the economy, and the neoliberal construction of civil engagement as working hard in that economy are particularly evident in Ontario's educational reforms; these new foci becoming sources of enchantment for policy makers and, ultimately, school administrators, teachers, parents, and students. Enchantment, as such, is fuelled via consistent, persistent, and ubiquitous promises of an education that increases earning power and productivity, and develops the tools needed to navigate a constantly changing marketplace after graduation, points of fixation across all areas of school life. 


\section{Ontario's Education for a New Millennium}

What follows is a brief summary of the specific neoliberal, careerist dictates found in the policy and curriculum documents generated by the new governments reforms; those highlighted demonstrate the scale and sweep of this culture in Ontario's schools. The policy document positioned as a "complement" to all policy documents including curricula is Choices into Action: Guidance and Career Education Program Policy for Ontario Elementary and Secondary Schools 1999 (Ministry, 1999, p. 3). In shaping the school lives of students from Kindergarden to graduation, the overriding rationale of Choices stipulates that

For their educational, social, and career success in the twentyfirst century, students will require effective work habits and the ability to make sound decisions, solve problems, plan effectively, work independently, communicate well, research, evaluate themselves realistically, and explore new educational and career opportunities. (p. 5)

Three core areas promote this goal: student, interpersonal, and career development. Ultimately the specific expectations for career development establish a direct link between education and the economy, individual responsibility for well-being in school and work, and a specific linkage among "work, society, and the economy" (p. 10).

Summarised in a table in the opening pages, these core expectations illustrate the centrality of career education, particular constructions of employment, and the social relations articulated by the economy and work. Students begin with a self-assessment of their skills and interests (p. 9). From there they move into exploring employment and education opportunities; starting in Grade 1 students are encouraged to link school to work via the curriculum by learning to identify "jobs and occupations in the community related to school subjects" (p. 10). The responsibility of the individual for wellbeing in work and the economy is threaded throughout the areas of Career Development and shape curricula content. Decisions that impact on school and work begin in Grade 1 and students are expected to develop competence in doing so (p. 10). Managing changes in the economy becomes an individual responsibility from Kindergarden when students are to "describe the connections between individuals and work (e.g., employees work for companies, which pay them a salary) ", through to Grade 7 when students learn how to "describe sectors of the economy in the local, provincial, and global economies", and finally into secondary school when this knowledge is thought to help students "describe how changes taking place in the economy, the envi- 
ronment, and society affect the job market" (p. 10). An awareness of employment opportunities in secondary school includes "self-employment" (p. 10). In relation to their "employability", secondary students must demonstrate an awareness of what are termed "employability skills" and "evaluate their personal, educational, or career plans in light of their community or workplace experiences" (p. 10) bringing lived experiences of work into the classroom.

The design of the new secondary school diploma was contained in Program and Diploma Requirements 1999. In the opening pages it promised a programme "designed to equip students with the knowledge and skills they will need to lead satisfying and productive lives" by preparing them for "further education and work" through a standardised curriculum "that is relevant to society's needs and expectations" (Ministry, 1999b, p. 6). Out of a total thirty credits needed to graduate only twelve remain open to student choice. The programme goals designate lifelong learning and career planning as key areas for individual growth. The foundations of Career and Guidance Training are described as a "vital and integral part" of secondary schooling (p. 45). A compulsory course called Career Studies is offered in the second year of secondary school when students are aged 15 years.

The course content and expectations of Career Studies are clustered under three strands: "Personal Knowledge and Management Skills", "Exploration of Opportunities", and "Preparation for Transitions and Change" (Ministry, 2006). In the classroom students are directed through a variety of activities designed to map out their final years of secondary school and a path to the workforce. They do so by investigating economic trends and resulting job opportunities and familiarising themselves with the generic organisation of workplaces. They look at ways to search for work, participate in mock job interviews, and build a CV. Much of this is completed by working with the National Occupational Classification system which categorises approximately 25000 occupation titles to identify avenues of interest to them. The occupations are defined according to two criteria: skill types and skill levels (Ministry, 2006). Integrated across the content and learning activities are "Employability Skills" that are considered important for success in all work settings; these mimic, echo, and cite the skills, competencies, and behaviours listed in resource materials provided by the Conference Board of Canada.

Aside from Career Studies, The Ontario Curriculum Grades 9 to 12: Program Planning and Assessment 2000 enshrines in policy workplace skills geared towards market-based productivity across all disciplines. In the opening pages the reader is told that all curriculum has been designed to ensure Ontario's graduates "are well prepared to lead satisfying and produc- 
tive lives as both citizens and individuals"; the curriculum will also groom students "to compete successfully in a global economy and a rapidly changing world" (Ministry, 2000a, p. 3). These considerations are to be adopted by all teachers across disciplines (p. 4). In addition to establishing these goals, this document also ensures that all courses are mandated to include "Education for Exceptional Students", "English as a Second Language and English Literacy Development", "The Role of Technology in the Curriculum", "Career Education", and "Cooperative Education and other Workplace Experiences” (Ministry, 2000a).

The inclusion of technology training across the curriculum for courses outside of those designed for business and vocational training compels all teachers to "effectively plan for the integration of computers and information technologies into the teaching/learning process"; and students are compelled to "become familiar with a range of available software programs" (pp. 9-10). The rationale for this sweep: the "Increasing reliance on computers, telecommunication networks, and information technologies in society and the workplace makes it essential for students to become computer literate" (p. 9). In the curriculum documents for specific disciplines such as English, Career Education as a specific heading appears. In 2000, the expectations in English included providing "opportunities for students to apply their language skills to work-related situations, to explore educational and career options, and to become self-directed learners" (Ministry, 2000b, p. 111). Across compulsory and optional courses at all ability levels, students in the English classroom "need to realize that literacy skills are employment skills" as "Powerful literacy skills will equip students to manage information technologies, communicate effectively and correctly in a variety of situations, and perform a variety of tasks" (p. 111).

\section{A Not - So - Public Pedagogy}

A critical reading of these documents provides insight into the private, neo-liberal interests and ethos that have come to inform life in the public sphere of education via policy, the curricula it creates, and the activities in classrooms that both serve to shape. Ontario's reforms were purported to make students more effective in managing change by making schooling responsive to the demands of the economy and global markets. In a time of economic downturn the reforms were positioned by the Conservative government as emancipatory, but student emancipation was equated with survival in the market place.

This turn, Taylor (2005) asserts, took education in Ontario beyond the human capital approach and an emphasis on quantity, to equate education 
with economic growth and place a new emphasis on distinct qualities linked to "vocational relevance" (p. 322). The emphasis placed on mirroring the workplace in school life, generic training to acclimatise students with the 'workplace', and the centrality of careerist thinking cemented the neoliberal focus on the individual and the market. The Ontario Curriculum Grades 9 to 12: Program Planning and Assessment 2000, an umbrella policy, ensures the inclusion of "Education for Exceptional Students" and "English as a Second Language and English Literacy Development" across the curriculum. However, alongside these "The Role of Technology in the Curriculum", "Career Education", and "Cooperative Education and other Workplace Experiences" are also promised (Ministry, 2000). Thus concerns for the collective including the literacy and language skills that allow citizens to participate in a democracy, and the rights to access an education by the disabled, were given equal time with school-to-work transitions and technological training (Martin, 2011).

The emphasis on 'choice' in the title of an umbrella policy document, the emphasis on a 'career' in its ethos, the use of the word competition, and repetition of these three words throughout policy and curriculum echoes the benchmarks of individual choice and the freedom to access and thrive in a competitive marketplace that underpin neoliberal doctrine. 'Choice' is the presumed ethos but choice is problematised by the emphasis on technical and vocational training: only one technical course is compulsory, however the mandate for technology training across all courses ensures vocational training that could be provided by employers is now publicly-funded (Martin, 2011). The emphasis on 'choice' in mapping a future is particularly ironic as more than half of the courses required for graduation became compulsory courses designated by the government in order to make students marketable upon graduation. The half-credit course Career Studies is particularly problematic in this regard: that careerist education is mandatory early in secondary school is emblematic of the government's commitment to the neoliberal agenda. The word 'career' in the name of this course and as it appears in curricular expectations across disciplines articulates particular, privileged connotations, while its content offers new subjectivities for students as workers. The word is defined sweepingly as the "sum of one's experiences in a variety of roles throughout life...which includes all of the individual's work, learning, community, and family roles" (Ministry, 2006, p. 26), effectively transforming a 'life' into a 'career'.

The content of the Career Studies course that grooms students for the workplace is an overt neoliberal turn. Drawing consistently on the the National Occupational Classification system in the course content year after year allows the message to stand that there are over 25,000 jobs availa- 
ble in times of economic boom or bust. The occupations listed are defined according to two criteria: skill types and skill levels, making a job reducible to what an individual does and how well he or she does it (Martin, 2011, p. 6). The co-operation of the Conference Board of Canada in designating "Employability Skills" around which the course's activities and assessments are clustered raises questions concerning the privileging of private, corporate interests as core values, and the role of 'corporate Canada' in designing curriculum. According to its website the Conference Board of Canada is a not-for-profit organisation with members from both the public and private sectors. Described as "objective and non-partisan" and "funded exclusively through the fees" charged for services provided to "the private and public sectors", the organisation's website describes themselves as "Specialists in economic trends, as well as organizational performance and public policy issues" and take a "business-like approach" to operations. The organisation is "Independent from, but affiliated with, the Conference Board, Inc., of New York which serves some 2,500 companies in 60 nations".

In addition to multinational and national corporations and companies, many of Ontario's public school boards are listed as members (Conference Board of Canada, 2012). Having partnered with school boards, the Conference Board of Canada created a poster and pamphlets under the banner Employability Skills 2000+ and both are widely available and visible in guidance offices and classrooms across Ontario. Not only have these materials been incorporated into the lesson plans of many teachers offering Career Studies, but are in use across disciplines. This publication lists "the skills YOU need to enter, stay in, and progress in the world of work" and "the employability skills, attitudes and behaviours that you need to participate and progress in today's dynamic world of work". The document lists and describes a variety of skills and knowledge specific to the use of technology, flexible work environments and continuous change in the economy (Conference Board of Canada, 2000). The emphasis on "you" directs the student to consider that economic sustainability is within the reach and control of the individual in the open marketplace. In return, employment is within the control of the individual who chooses to follow (Martin, 2011). Employment or unemployment is simply another choice.

The inclusion of these skills, drills, and competencies into the curriculum and the teaching materials marks a blatant extension of the mantras of corporate Canada in the educational design, delivery, content, and resources used by teachers and students (Martin, 2011). According to a study of the school-to-work mandate in policy and curricular reform in Ontario, the partnership model designed by the government to implement school-towork programming failed to "engage the perspectives of organised labour 
and educators" to balance what is referred to as the "employers' focus on productivity“ (Taylor, 2005, p. 336). The emphasis in the language of policy and curriculum on "employability" over "employment" was sited as a shortcoming by organised labour; this same emphasis, Taylor (2005) offers, has shifted the focus from opportunity and social mobility to employability and productivity (pp. 333-337), and clearly privileges the positions of employers and educating for the economy over the needs of individuals and societies.

On the cusp of these particular changes, Barlow et al. (1994, p. 121) observed that "right-wing education reform must be couched in the language of excellence and achievement" in order to gain the support of voters, parents, and students. A crafted message that blends excellence, achievement, and efficiency, and the sweep and repetition of this message, is the key to the resilience of the neoliberal agenda: how is a parent or a student to deny 'excellence' and 'achievement' in education, or to deny either when it is offered by the state as politically neutral and as law? 'Potential' in all its permutations, for individual students and the economy, became the technology that justified the reforms. If capitalism offers only a "future-tense narrative of inevitability" (Medovoi, 2002, p. 66) then market-led education in Ontario works with the same language. In the classroom capitalism's narrative serves as a snare: its threat and promise are connected to a time and place in the offing, but students learn that their successes or failures in the marketplace of the future are grounded in choices they make in the present.

\section{Reform, Remediation, and Resilience}

A crisis of failure(s) followed the implementation of these reforms. When the Conservative government failed in its bid for a third electoral victory in 2003, instability in education was cited as a key area of disenchantment among voters. What follows is a look at the implications of this instability for students, namely the decline in graduation rates and the remedial measures taken by the new government to address this decline. These remedial measures continue to echo the earlier government's formulation of - and formula for - 'success' in the marketplace via education and illustrates the resilience of these neoliberal benchmarks.

In the early years of the new Liberal government under Dalton McGinty, a report by King (2004) in the province estimated that approximately 25\% of the students who enrolled in Grade 9 in the first year of the reforms would not graduate (as cited in Taylor, 2005, p. 328). The government reported that prior to the reforms the graduation rate had been $78 \%$; at the end of the 2004-2005 school year 68\% or 51,000 of Ontario's students had left secondary school without having enough credits to graduate (Ministry, 
2005). Widely reported in the media, teachers' union studies, and educational research released over the following year, the number of students who were able to graduate at the end of four years was approximately $60 \%$; of the remaining $40 \%$ some would drop out and some would return for a fifth year in the hopes of graduating the following spring (Ontario Secondary School Teachers' Federation, November, 2006). The numbers suggested that instead of higher standards for all via a stream-lined, rigorous curriculum and standardised testing, these results demonstrated a polarisation that mirrored that of the labour market at large (Taylor, 2005, p. 330).

In 2005 a $\$ 1.8$ billion (CDN) three-phase remedial project under the banner of Student Success was launched in Ontario to address the needs of students considered at risk of not graduating (Ministry, 2005). Aside from immediate, school-based measures to curb 'drop-out', changes in the policy and curriculum documents came under consideration. The aim: revise education policy to articulate a new definition of success and increase graduation rates amongst groups identified as at-risk following the reforms. Both curricula and the umbrella policies were subject to remediation. That said, the emphasis on education for a strong economy persists in spite of the early results that indicated that, for whatever reason, students did not buy in to the promise.

The Career Studies course was revised in 2006. The ideological foundations described in this article are based on that revised document; a review of both the original course and the revised curriculum of 2006 reveals a continued emphasis on employability and individual responsibility for seeking, sourcing, and securing employment. The new document, like the original, does not designate space for organised labour or collective bargaining. Likewise the message persists that changes in workplaces and the labour market at large are inevitable and it is the responsibility of the student/ worker to navigate those changes to sustain employment. Remediation of the reformed curriculum documents in subjects like English did not remove language related to workplace skills and competencies.

Program Planning and Assessment 2000 was expanded beyond secondary school when replaced by Growing Success: Assessment, Evaluation and Reporting in Ontario Schools First Edition, Covering Grade 1 - 12 in 2010. The second chapter entitled "Learning Skills and Work Habits in Grades 1 - 12" offers that success across disciplines "is closely tied to learning skills and work habits" (Ministry, 2010, p. 10). Like its predecessor, this document directly connects the consolidation of work habits across a student's school life "in preparation for postsecondary education and the world of work" (p. 12). The development of this document prompted the creation of the Ontario Skills Passport, based on research conducted by the Min- 
istry, the federal body Human Resources and Skills Development Canada (HRSDC), and the Conference Board of Canada (p.12). The Ontario Skills Passport "identifies and describes the following important work habits: working safely, teamwork, reliability, organization, working independently, initiative, self-advocacy, customer service, and entrepreneurship“ (p. 12).

Program and Diploma Requirements 1999 was also expanded beyond secondary school and was replaced in 2011 by Ontario Schools, Kindergarten to Grade 12: Policy and Program Requirements 2011. The new document maintains the emphasis on career education as a part of schooling for children from the first year they enter school at age five through their graduation from secondary school at age eighteen. Designated as a "learning program", every school in the province school is required to design and deliver a programme for guidance and career education (Ministry, 2011, p. 25). Programmes are to be designed to address three areas of learning that include: student, interpersonal, and career development. The latter is described as "the development of the knowledge and skills needed to set short-term and long-term goals in planning for the future“ (p. 25). Thus, students remain responsible for what is to come based on what is in present. All schools are mandated to "offer a range of career exploration activities" that will foster students" "competencies" such as self-awareness, "exploring opportunities", "making decisions", and "preparing for change and making transitions" (p. 26). The document emphasises that across a student's entire school life the programme opportunities will come from schools and the encouragement from teachers. However, in deference to the individual's control and power over his/her commitment to success, students will "set goals to improve their work and to review the success of their personal efforts and choices" ( $\mathrm{p}$. 26). Readers are reminded that in order to graduate from secondary school, all students are required to successfully complete the Grade 10 career studies course", and students have the option to "take additional courses from the guidance and career education curriculum policy document" (p. 26) if needed or desired.

For more detailed references to competencies and specifics of career and guidance education the reader is, again, referred to Choices Into Action 1999. The resilience of this document in the remedial reforms remains to be seen: according to the website of the Ministry of Education (Ontario) Choices Into Action 1999 is under revision, and remains so at the time of writing.

The graduation statistics have, according to the government website, improved considerably in light of remediation and greater 'choice' for students in planning their post-secondary options, and through early intervention and supports across the system for students identified as 'at-risk'. A government release in 2011 of the statistics for the 2009-2010 school year 
indicate that $81 \%$ of students had graduated. However, in addition to remediation to the reforms, in 2007 students became subject to Learning to 18: a law that prevents them from leaving school until age 18 and prevents 'drop outs' from earning or keeping a drivers licence in Ontario. In recent years education across Canada, and in Ontario in particular, has been lauded as an example to the rest of the world based on the results of standardised tests. Nationally, drawing on statistics gathered by the Programme for International Student Assessment (PISA) at the OECD, Canada was ranked sixth of approximately 32 countries in 2009 according to an article on education in The Economist (2011). In the same article, Ontario received special attention by Sir Michael Barber namely for having "one of the world's best-performing school system" despite its "high proportion of immigrants" and their transitional and English-second-language needs within the system.

While graduation rates have increased some question the success of remediation at a micro level. As has been noted, many of the neoliberal fundamentals remains the same; according to Taylor (2005) "historical struggles over what is best for different groups of students continue“ as questions were raised about the validity of streaming at-risk students towards the workplace as their primary post-secondary destination (p. 329) rather than addressing their underrepresentation among applicants to college and university. The term "historical struggles" is particularly relevant in light of persistent failure rates noted within the system: in addition to class-based disparities, disparities in the provision of education in Canada related to race and ethnicity are also well documented. According to current research, the outlook for many students in Ontario remains bleak among some immigrant and ethnic groups, despite Barbour's observation. A recent article in the University of Toronto Magazine offers that among aboriginal, Middle Eastern, Central and South American students, and students from the Caribbean, early-school leaving rates are often higher than 40\% (Macdonald, 2011).

In Toronto, among first-generation Latin American youth alone, the rate of early-school leavers is approximately 37\% (Anderson, 2011, p. 32). Citing the work of Professor Ruben Gaztambide-Fernandez of the Ontario Institute for Studies in Education at the University of Toronto, this particular group of students are very aware of the connection between acquiring an education and the potential for a secure future. Thus, he concludes, "The situation that leads them to leave school really has nothing to do with how committed they are to school“ (qtd. Anderson, 2011, p. 32). Based on interviews conducted with students, he asserts that the cuts to education across the 1990s that reduced the resources available for English second language instruction and a curriculum that does not have room to include the history and culture of Latin American students has put them at a disadvantage. 
Finally, the choices these students have to make that impact directly on their academic achievement may be shaped entirely by what the researcher refers to as "their social and economic circumstances": they may need to work evenings to contribute to the family economy or "choose an academic path that is less than appealing to them if it holds the promise of being able to obtain a job sooner" (p. 32).

\section{Conclusion}

That global capitalism has become a site of pedagogy in dictating what is taught and how in publicly funded classrooms challenges the validity of calling education 'public' despite its funding source and the elected administrators who articulate the mandates of this same education. In the same spirit that transformed global capitalism on the threshold of the twenty-first century into 'millennial capitalism' (Comaroff \& Comaroff, 2000), education in Ontario became millenarian via reforms that mirrored those of global, free-market capitalism: economic survival became the responsibility of the individual/student and not the government in an arena shaped by nebulous market forces. While there is an inclination to conceptualise these reforms as a contemporary 'pedagogy of the oppressed', Ontario's schools came to offer what is instead a pedagogy of the inoculated. Schooling as an elixir against economic instability points to a single theme: mastery of the spectral technologies often cited by capitalism's critics as its failings. Thus, students are promised the skills, competencies, and behaviours they are told are needed to survive in the global economy as subjects of flexible workplaces, fickle labour markets, and deregulated financial markets. Capitalist restructuring moved beyond the economy itself and into education specifically to shape potential workers and producers who want more control over individual financial security.

It is at the moment of this restructuring under a neoliberal agenda that schooling is "reoriented": students as individuals are prompted to develop "a self in relation to the market rather than the state" (Sears, 2003, p. 11). Interviews with representatives from government, the business community, organised labour, education, and others involved in Ontario's schoolto-work policy in Ontario highlights the vulnerability of schools and students under the ethos of these reforms. According to Taylor (2005, p. 322), a review of these interviews indicates that a tension exists between "the rhetoric of enhancing opportunities for students and the reality of lower graduation rates associated with the new curriculum". Further, a neoliberal style of policy development in education decreases opportunities specifically for 
students who will not be attending university or college after completing secondary school.

The example of Ontario's reforms at the turn of the millennium, the crisis that resulted, and the remediation that followed are instructive in the current recession and ongoing calls for 'value-for-money' in delivering public services, and overall competitiveness. Further, the system-wide remediation provides a view into the resilience of neoliberal education reforms and the neoliberal message. Ultimately, a question about both democracy and valuefor-money looms: it is the role of publicly funded schools to provide training in skills and to respond to the needs of the private sector? Is this an efficient or prudent use of scarce public funds?

\section{References}

The great schools revolution. (2011). The Economist. Retrieved 15 June, 2012, from http://www.economist.com/node/21529014/print

Anderson, S. (2011). Education for all: Why do some immigrant groups fare better than others in school? University of Toronto Magazine (Winter 2011), 32.

Barlow, M. (1994). Class warfare : the assault on Canada's schools. Toronto : Key Porter Books.

Comaroff, J., \& Comaroff, J. (2000). Millennial capitalism: First thoughts on a second coming. Public Culture, 12(2), 291.

Conference Board of Canada (2000). Employability skills 2000+. Retrieved 15 June, 2012, from http://www.conferenceboard.ca/Libraries/EDUC_PUBLIC/esp2000.sflb

Conference Board of Canada. (2012). Accessed 15 June 2012. www.conferenceboard.ca.

Giroux, H. (2000). Public pedagogy as cultural politics: Stuart Hall and the 'crisis' of culture. in S. Hall, P. Gilroy, L. Grossberg, \& A. McRobbie (Eds.), Without guarantees : in honour of Stuart Hall (pp. 134 - 147). London New York : Verso.

Giroux, H. A. (2004). The abandoned generation: Democracy beyond the culture of fear. New York: Palgrave Macmillan.

Giroux, H. A. (2006). America on the edge: Henry Giroux on politics, culture, and education. New York: Palgrave Macmillan.

Macdonald, C. (2011). Different but equal: Is greater choice in alternative education good for Toronto's schools? University of Toronto Magazine. Retrieved 12 June, 2012, from http://www.magazine.utoronto.ca/feature/chris-spence-toronto-boardof-education-africentric-schools /

Martin, S. M. (2011). Downloads: Attitudinal grooming in Ontario's schools. Critical Social Thinking Conference Proceedings, University College Cork, Ireland. Retrieved 4 July, 2012, from http://www.ucc.ie/en/appsoc/researchconference/conf/csti/ CST2ndAnnualConferenceProceedings2011/ 
Ministry of Education (2005). Transforming high schools: Ontario's Student Success Strategy. Retrieved 4 July, 2012, from http:/www.edu.gov.on.ca/eng/document/ nr/05.12/bg1208b.pdf

Medovoi, L. (2002). Globalization as narrative and its three critiques. Review of Education, Pedagogy \& Cultural Studies, 24(1/2), 63.

Ministry of Education (1999a). choices into action: Guidance and career education program policy for Ontario elementary and secondary schools 1999. Toronto: Queen's Printer for Ontario.

Ministry of Education (1999b). Ontario secondary schools grade 9 to 12: Program and Diploma Requirements 1999. Toronto: Queen's Printer for Ontario.

Ministry of Education (2000a). The Ontario curriculum grades 9 to 12: Program Planning and Assessment. Toronto: Queen's Printer for Ontario.

Ministry of Education (2000b). The Ontario curriculum: grades 11-12 English. Toronto: Queen's Printer for Ontario.

Ministry of Education (2006). The Ontario curriculum grades 9 and 10: Guidance and Career Education (revised). Toronto: Queen's Printer for Ontario.

Ministry of Education (2010). Growing success: Assessment, evaulation, and reporting in Ontario's schools. Toronto: Queen's Printer for Ontario.

Ministry of Education (2011). Ontario schools, kindergarten to grade 12: Policy and Program Requirements, 2011. Toronto: Queen's Printer for Ontario.

Ontario secondary school teachers' federation, education services committee (November 2006) OSSTF Critical Issues Series. Vol. Monograph \# 37. Graduates Versus Dropouts: A Statistical Nightmare. Retrieved 4 July, 2012, from http://www.osstf.on.ca/ Default.aspx?DN=7dd29d0d-fa85-4aeb-9788-fa682b6e9ee5

Sears, A. (2003). Retooling the mind factory : Education in a lean state. Aurora, Ont. : Garamond Press.

Stephens, S. (1995). Introduction: Children and the politics of culture in 'late capitalism'. In S. Stephens (Ed.), Children and the politics of culture (pp. 3 - 48). Princeton, N.J. : Princeton University Press.

Taylor, A. (2005). 'Re-culturing' students and selling futures: school-to-work policy in Ontario. Journal of Education and Work, 18(3), 3321-3340.

\section{Author:}

Susan Marie Martin, PhD. candidate

National University of Ireland

University College Cork

Department of Applied Social Sciences

c/O D.A.S.

P.O. Box 5262

Damman

31422

Saudi Arabia

email: smariem13@gmail.com 